\title{
Public Pressure, Temptation of Power and Unconstitutional Actions in the War Against Terrorism in Kenya: Suggesting a Link
}

\author{
CecilYongo *
}

\begin{abstract}
The reaction of the government in Kenya, like many other governments around the world, to terrorist attacks has generally been to strengthen existing laws and enact novel laws, especially those that aid the state's intelligence-gathering capabilities, along with those that are punitive. In some cases, even in Kenya, States have taken, or have attempted to take, extra-Constitutional and unconstitutional actions. This is the approach that this paper characterises as arising from 'temptation of power', and in that regard, this interdisciplinary paper is-through an analysis of scholarship in law, sociology and information/ communication-an attempt to investigate the origin, results and wisdom of such an approach in the war against terror, its effect on the rule of law and minority rights in society; and propose why and how it can be avoided.
\end{abstract}

\section{Introduction}

If one would, of late, ${ }^{1}$ say that the nation of Kenya has become a haven for terrorists, one would have good reason with reference to the line of terror attacks that the nation has suffered, almost consistently, in the last four years. ${ }^{2}$

What catches the eye of any keen observer from this catalogue ${ }^{3}$ is not that there have previously occurred much fewer terrorist attacks in Kenya ${ }^{4}$ but rather

* The author is a student at the Strathmore University Law School in Nairobi, Kenya. In its writing and compilation, the author benefited enormously from the advice and editing of many but especially one Ms AnnBeatrice Njarara, for whom much gratitude is, as a result, owed.

This paper was first written and compiled between April and May 2015.

2 See the escalation in terror attacks in Kenya in a list detailing each attack's location, nature, death and injury toll at https://docs.google.com/spreadsheets/d/1r3FAovpHPMjaU234VwyuM5Qxg95 11zXVRJjqeG9AIZc/edit\#gid=0 on 11 December 2015.

3 https://docs.google.com/spreadsheets/d/1r3FAovpHPMjaU234VwyuM5Qxg9511zXVRJjqeG9A IZc/edit\#gid=0 on 11 December 2015.

4 See Federation of American Scientists Accountability Board Report, Report on the bombings of US 
the way in which the attacks escalated, and then became common fold, so much so that only the ones in which a huge number of people lost their lives, or were injured, elicited response from the highest echelons of government. And since this is a paper that attempts to prescribe, dissect, analyse and correct what it is that leads to government actors' sometimes unconstitutional response/s to terrorism, it is prudent to begin by looking at how government actors did indeed respond to the terrorist attacks. And it follows that to successfully look at how government actors (whom I hereafter refer to simply as 'government' or 'the state') unconstitutionally reacted to the attacks, it is necessary that one begins by looking at the events, and then examine the pressures, that come with the different terrorist attacks in Kenya.

\section{The influence of the press and the national mood after terrorist attacks}

To understand the state's response to terrorist attacks, one must begin by formulating an imaginary dichotomy of terrorist attacks in Kenya; the minor terrorist attacks and the major terrorist attacks. This differentiation is informed not by a failure to appreciate 'lesser' human life lost, the pain of loved ones and fear of those who witnessed the act—no matter how small—but rather by the nature of the public mood (or opinion) itself. For the purposes of this paper, we will examine 'public opinion' as per the critical theory of information and communication. Under it, public opinion is an imaginary, ideal, and utopian referent that serves essentially as a legitimizing principle for political discourses and actions. More concretely, it is the fragmentary result of the public diffusion of speeches made by the political class and the media. Public opinion, though thought to be so, is not the sum of individual opinions but is constructed by social actors interested in linking their plans to the people's will in order to increase their legitimacy. This perspective rests on a profound intellectual disagreement with the liberal-pluralist-positivist perspective. ${ }^{5}$

Embassies in Nairobi, Kenya and Dar es Salaam, Tanzania on 7 August 1998, January 1999, fas.org/irp/ threat/arb/accountability_report.html on 7 December 2015. On August 8 1998, the American Embassy in Kenya was bombed, leaving about seven people dead and seventy two others injured, while on 28 November 2002 Israeli-owned Paradise Hotel faced the brunt of a terrorist attack that saw Al-Qaeda suicide bombers carry out an attack that left 15 dead and destroyed the establishment. Apart from these, terrorist attacks have in previous years, before 2011, been almost non-existent.

5 See Gingras AM and Carrier JP, 'Public Opinion-Construction and Persuasion' 21 Canadian Journal of Communication, 4(1996), 14. 
Indeed, in all this, one should also see that the public mood can be, and is, set and read by the press. The press is, in the words of V.S Yarros, 'the director and moulder' of public mood. ${ }^{6}$ Indeed, Pierre Bourdieu's Article 'L'opinion publique n'existe pas', published in $1973,{ }^{7}$ is the main reference point for this claim. Bourdieu asserts that public opinion is really just a construct of power relations, with those in control (led by the media) being the primary driving force behind it. Anne-Marie Gingras and Jean-Pierre Carrier have also gone on to say that

'Public opinion is captured partly or mainly through the press, moulded by it, influenced by it, or plainly created by it. Although the nature of the link between public opinion and the press remains ambiguous, the very existence of this link is incontestable.8

One may say that the advent of the use of social media tools means that the press is relied on less and less to form public mood, but this would be missing the point that even the agenda on social media itself is formed by the reportage of the day and so it can be said that it is a closed loop that starts with the press. This is known as agenda-setting, the theory that the more attention a media outlet pays to a certain phenomenon, the more importance the public attributes to such an issue. ${ }^{9}$ And key about the press is that it is becoming apparent to keen observers that the trend of interpretive or advocacy journalism rather than reporting journalism has begun to seep in. This is the time when journalists come to see themselves as creators of news. They do not see themselves as recorders anymore but rather as shapers of events, with a self-constituted responsibility to history; duty binds them to their deadlines and conscience to their self-constituted responsibility to the people. It is the constant winging of these reporters on the failures of the state in these attacks, and the reaction to them by the public in mood, a reaction particularly able to be brought out by the power of social media, that pressures the state to respond to a terrorist attack.

6 See Yarros VS, 'The Press and Public Opinion', 1899-00, 5 American Journal of Sociology, 372. The liberal-pluralist-positivist school of thought in Information and Communication, however, insists that a scientific national poll is probably the best way that a 'national mood' on an issue can be known. Still, these polls are not conducted on every issue and yet a national mood can still be inferred; perhaps the best example of this inference being made may be found when judges are making rulings and judgements. This author had the privilege of interviewing a High Court judge (notes with the author) who listed criteria considered when making judgements, one of which was 'the prevailing public mood.' In answering the question on how he was possibly able to know what the public mood on an issue was, the Judge's response was simple: read news, watch news. The press. Bourdieu P, 'L'opinion publique n’existe pas’ Modern Times, January 1973, 1292-1309.

Gingras AM and Carrier JP, 'Public Opinion-Construction and Persuasion', 6.

9 See Malcheff M, 'Public Perception of Media Manipulation: the Power of the Agenda-setting function of the Press Examined', Master Thesis Paper, Liberty University, 9-11. It is also available on Academia.edu. 
The truth in this country is that, spurred by the press, the public mood pays little attention to death or injury of a small number of people in a terrorist attack, thus I call this a minor terrorist $\operatorname{attack}^{10}$ and pays just a little more attention to the death and/ or injury of a larger number of nondescript people in a terrorist attack, and thus I also call this a minor terrorist attack. ${ }^{11}$ What the public mood has been seen to pay attention to for the longest time in this country is the death and/ or injury of a very large number of people, nondescript ${ }^{12}$ or elite, ${ }^{13}$ and the death or injury of a small number of people who are part of the elite. Tony Bennett also observes this trend in his writing; ${ }^{14}$ and these I call major terrorist attacks.

There is normally a gulf difference in the way that the state responds to minor terrorist attacks as compared to the way it responds to major terrorist attacks. Typically, a minor terrorist attack will attract a minor response from government, and vice versa. In the aftermath of a minor terrorist attack, for instance, a local police chief may issue a roadside statement to the press as Mandera County Police Commander Job Boronjo did on February $5^{\text {th }} 2015$, after a grenade attack injured eight people at a café. ${ }^{15}$ At best, the National Police Chief may issue a statement to guide the press on what happened and appear to be in charge of the situation, as happened in 2012 when then-National Police Commissioner Mat-

10 For instance, the national newspaper the Daily Nation, the most circulated daily newspaper in Kenya according to the Audit Bureau of Circulation of Kenya (standing at about 120, 000 copies daily), gave the attack on 18 April 2013 at the 'Kwa Chege' Hotel in Garissa, Northern Kenya, only minor mention on page 3 for one day. Prime-Time news carried it as a third (NTV Kenya), or fourth (Kenya Television Network) news item, after exhausting their reporting on the day's major events.

11 The attack on 14 December 2013 where a hand grenade was thrown into a minibus in Eastleigh, Nairobi leaving 4 dead with over 36 wounded, was given more mention than that described in footnote 16, but for just two days of national news, in both national newspapers; the Daily Nation and the Standard.

12 Compare the prior reaction to the reaction after the attack that took place in Garissa University on 2 April 2015 (in which a whopping 147 died while 79 were injured) where the national news reported on the attack and called for action for over one and a half weeks. In addition, candles were lit and memorial concerts were organized for the bereaved.

13 The attack on the Westgate Mall was perhaps, the best example of this. Reporting on the attack continued for over a month, at first constituting almost 7 pages of national newspapers and several items on prime time news before easing off. In addition, many special monetary contributions were made and the public hashtag 'we are one', to signify national unity, trended on the social media site Twitter.

14 See Bennett T, Critical Trajectories: Culture, Society, Intellectuals, Blackwell Publishing, 2007, 141-163.

15 In Mr. Boronjo's words; "Security officials are currently on high alert following information of a planned attack by Al Shabaab in the region," he said, adding that "Police are looking for suspects reportedly from Somalia on a mission to cause havoc in the country." See more at http:// morningstarnews.org/2015/02/eight-people-injured-in-grenade-attack-in-northern-kenya/on 11 May 2015. 
thew Iteere issued a statement in the aftermath of a grenade attack at the Bella Vista night club in Mombasa on May $15^{\text {th }}$ which killed a woman and wounded several people, and for which Al Shabaab were quick to claim responsibility. ${ }^{16}$ This holds firm most times, until one considers the phenomenon of the bored press. As this paper attempted to show previously, public mood is set and read by the press many times, and when there is a dearth in 'big' news items to report ${ }^{17}$ in the news cycles, there is a possibility whereupon issues that would otherwise have attracted short news and blown over are sensationalized. This is called 'yellow journalism' and a treatise on it has been written by W. Joseph Campbell. ${ }^{18}$ In this case, the state becomes prey with the press on the hunt. Perhaps only then will a minor terrorist attack, in turn, attract serious state response.

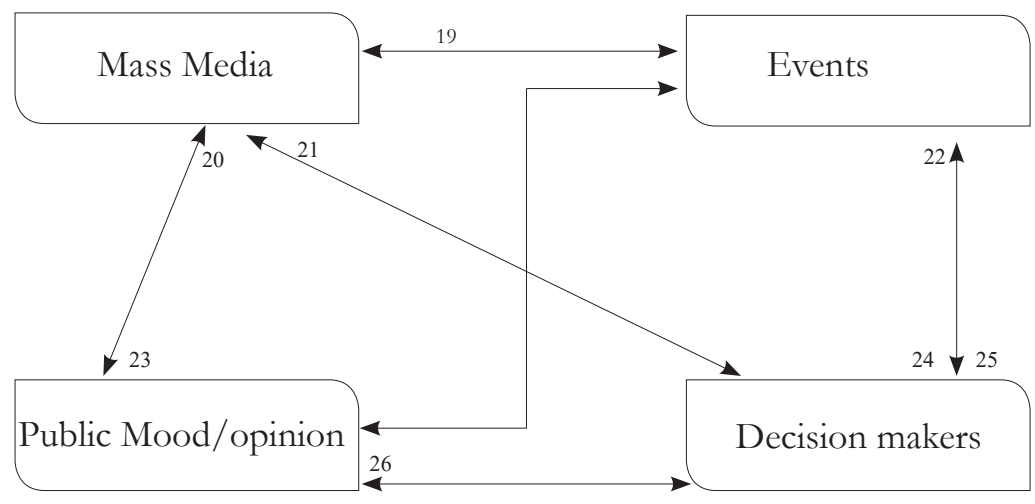

16 See more at http://www.tourismupdate.co.za/home/detail?Articleid=25139\&Article=kenyagovernment-responds-to-grenade-attack on 11 May 2015.

17 Normally major political news, events and drama.

18 See Campbell JW, Yellow Journalism: Puncturing the Myths, Defining the Legacies, Praeger Publishers, 2003, wholly relevant.

19 See Gartner S, 'Casualties and public support: an experimental analysis', Presented at Annual Meet of the Political Science Association of Philadelphia 2006, wholly relevant.

20 See Dijk TA, 'Power and the News Media', University of Amsterdam, 19-21.

21 See Baum M and Potter P, 'The Relationships between Mass Media, Public Opinion: Toward a Theoretical Synthesis' Annual Review of Political Science, University of California, 2008, 48-51.

22 See DeRouen K Jr. and Peak J, 'The Dynamics of Diversion: The Domestic Implications of Presidential Use of Force, International Interactions: Empirical and Theoretical Research in International Relations', Routledge Publishers, 2002, 191-211.

23 See Dijk TA, 'Power and the News Media', 13-16.

24 See Baum M and Potter P, 'The Relationships between Mass Media, Public Opinion: Toward a Theoretical Synthesis', 49-50.

25 See Perl R, 'Terrorism, the Media and Government: Perspectives, Trends and Options for Policymakers', 22 October 1997, available here: http://www.au.af.mil/au/awc/awcgate/state/crs-terrormedia.htm on 16 May 2015.

26 See Briant E, 'The struggle for Public Opinion within the Media and the Information War on Terror' in 'The Media: The Terrorists' Battlefield' Centre for Excellence Defence against Terrorism (2007), 89. 


\section{Temptation of power}

The way in which the state responds to a major terrorist attack is a whole other matter and it is this that one must linger on, for it is this that forms background for what this paper calls 'temptation of power.' If one were to draw a recent-day 'major terrorist attack' list in this country, it might read something as follows: the September $21^{\text {st }} 2013$ attack on the Westgate Mall, the June $15^{\text {th }}$ 2014 attack in Mpeketoni, the November $23^{\text {rd }} 2014$ bus attack near Mandera, the December $2^{\text {nd }} 2014$ quarry attack in Koromey, Mandera and the April $2^{\text {nd }} 2015$ attack on Garissa University College, Garissa. There is no doubt that these attacks stunned the national conscience, a conscience that had become used to, and therefore immune to, being awoken, by minor terrorist attacks. So how was such a national conscience awoken? In the same way that you awake someone who is asleep; you shout louder, you shake them harder, you hit them harder. And this is exactly what the terrorists did in these attacks. ${ }^{27}$

When the national conscience is stirred, pressure is felt by those in power, those in authority. Transmitted, as this paper has belaboured, mainly by the press, this pressure is also ramped up by other caucuses of society, ${ }^{28}$ and made out even better by a society that is on the edge. ${ }^{29}$ It is this pressure that leads to what this paper calls temptation of power. The temptation of power, first broached by Theodore H. White ${ }^{30}$ but today understood varyingly, ${ }^{31}$ starts with the impatience

27 From killing and injuring under 20 in the prior grenade attacks, Al Shabaab killed a shocking 65 and injured 175 others at the Westgate Mall; killed 28 in the Mandera bus attack; killed 36 in the Koromey Quarry attack and killed 147 in the Garissa University College attack.

28 For an academic study of this, see Baroni L et al, 'Defining and classifying interest groups' 3 Interest Groups \& Advocacy Journal (2014), 141-159. In Kenya, the church, for instance, spoke out: See more at http://www.standardmedia.co.ke/Article/2000158909/why-church-is-angry-over-repeatedterror-attacks on 11 May 2015. So did the Law Society of East Africa and the Kenyan National Union of Teachers.

29 There may be few other ways to describe the Kenyan society after these attacks; Text messages urging people to stay away from places that they usually frequented are sent back and forth (of which this author has received many) and perhaps the best example of the society being on the edge may be the events on April 132015 at the University of Nairobi's Kikuyu area campus where one student died and over one hundred were injured as students took part in a stampede (with some jumping from high floors) after they misjudged what was an electric cable burst to be a terrorist attack. See more at: http://www.nation.co.ke/news/kikuyu-campus-stampede-transformerexplosion/-/1056/2683130/-/wbg1vxz/-/index.html on 11 May 2015.

30 White T, The Making of the President 1972, Atheneum Publishers, New York, 1973, 390.

31 'Temptation of Power' is today discussed more as a moral issue, that is, that leaders must be careful not to fall into the trappings of power. See for instance former Czechoslovakia President Václav Havel's speech when he accepted the Sonning Prize for his contribution to European civilization here: <https://www.cs.utexas.edu/users/vl/notes/havel.html on 15 May 2015. See also 
of a nation that demands quick solutions. The impatience of the nation is presented by society's caucuses, some of which have no names; an example of this 'caucus without a name' is the elite, the establishment. One will never walk into a room and find a gold plaque reading that " "the establishment' is meeting." One will, however, know when the establishment has met in thinking. This is indeed what happened after the attack on the Westgate Mall. For here, before their eyes, was the establishment's way of life being threatened; for this is where they went for their kaffeeklatsches', this is where their sons and daughters spent time on weekends. This is where the self-recognizing noblesse spent their free time. ${ }^{32}$ And this is where the terrorists had just hit. Thus all these caucuses apply pressure on those in power to act.

Now there is a membrane of law and morality that, indefinably, gives the state its sacerdotal quality. It is a delicate and flexible membrane which is vital; it must contain policy and national action within the law. When the membrane haemorrhages-danger. This membrane has definitely been strained and even broken many times before ${ }^{33}$ but that is not to say that it should continue to be broken. After all, the government is made of the law itself, and the law must be executed in all its precise purity. It is that pressure applied that tempts power to a final, poisonous rupture of the membrane.

Temptation of power usually stirs when those who wield it grow impatient at its limitations - and then the impatience affects everyone down the chain. Credit goes to those who respond the fastest, with the credit rising level by level to the Office of the President. The pressure on anyone who works in the national security apparatus of the President can be enormous, but so are the privileges. There is the government limousine, there is the guard sent to give his life, if need be, to preserve the privileged person's own. There is the deference from famous men who visit, from the bureaucracy below. It might exhaust-but it also

Hamdi S, Temptations of Power: Islamists and Illiberal Democracy in a New Middle East, Oxford University Press USA, April 2014 wholly relevant. For the purposes of this paper, the author adopts Theodore White's original conception.

32 It is instructive to note here that President Kenyatta himself lost a nephew and his fiancé in this attack. Hosting a children's' cooking contest and among the dead was also Ruhila Adatia-Sood, a Nairobi local who was a popular TV and radio presenter. Among the other victims was also Juan Ortiz Iruri, a Peruvian national who was a hugely experienced UN tropical diseases specialist who was about to begin work at the Liverpool School of Tropical Medicine (LSTM), a Diplomat and two Canadian nationals. Mr. Ravindra Ramttan, a winner of a presidential gold medal in Trinidad for his academic prowess, and Mr. Kofi Awoonor, a Ghanaian poet, academic and former diplomat. These men and women are no doubt part of the elite of our society.

33 The state is known to have acted in unconstitutional ways many times in Kenya's history, particularly in the years of the infamous 'Nyayo Torture Chambers', when the Moi government was in power. 
intoxicates. Beyond the pressure shimmer many dreams - and this is what causes those in power, and who face the pressures, to act on the temptation of power.

\section{The succumbing to temptation of power and the consequent damage to the rule of law and human rights}

Among the men who report and follow Government response to these major terrorist attacks, the initial reaction and response to the pressures that unveil the temptation of power has become almost predictable; a national address by the President ${ }^{34}$ that spurns themes such as unity, ${ }^{35}$ strength $^{36}$ and a coming justice. ${ }^{37}$ Such a speech will probably be buttressed by visits paid to the scene of the attack, to the victims of the attack, ${ }^{38}$ a letter to loved ones, ${ }^{39}$ and public pronouncement that the State will meet various costs accruing to those affected. ${ }^{40}$ A commission of inquiry was also once mooted. ${ }^{41}$ It is the reaction that follows these public-relation assurances that is interesting because it is in those reactions that we see the reach of the temptation of power.

We begin with the stretching of the membrane of law.

34 President Kenyatta religiously addressed the nation after the Westgate terrorist, the Mpeketoni attacks, the Koromey quarry attack and the Garissa University College attack. He only failed to address the nation after the Mandera bus attack, this because he was out of the country, in Dubai. Even then, he spoke after returning to the country.

35 In President Kenyatta's own words after the Garissa University College attack, "I urge every Kenyan, every church and every local leader to speak up for our unity and ensure that our justified anger does not spill over and lead to the victimization of anyone."

36 In President Kenyatta's words in an address to the nation after the Westgate Mall terrorist attack, "We confronted this evil without flinching, confronted our deep grief and pain, and conquered it."

37 In President Kenyatta's words after the Westgate Mall terrorist attack, "These cowards will meet justice as will their accomplices and patrons wherever they are."

38 See http://www.the-star.co.ke:8080/news/pictures-dp-ruto-condoles-garissa-attack-victims \#sthash. Qpr2JP4w.dpbs on 11 May 2015.

39 'Uhuru writes personal letters to each of the 147 Garissa attack families' The Star, 9 April 2015, www.the-star.co.ke/news/uhuru-writes-personal-letters-each-147-garissa-attack-families on 7 December 2015.

40 See http://www.northriftnews.com/dp-ruto-says-government-will-foot-medical-and-funeral-expenses-for-garissa-attack-victims/ on 11 May 2015.

41 President Kenyatta had promised, in his address to the nation after the terror attack at the Westgate Mall, to set up a Commission of Inquiry. This did not materialise, see more here: http://mobile. nation.co.ke/news/Commission-of-inquiry-that-never-was/-/1950946/2460374/-/format/ xhtml/-/1hga34/-/index.html on 13 May 2015. 


\section{i. The stretching of the membrane of law and the damage done to the rule of law}

Take the Koromey quarry terrorist attack, seemingly the apogee of this raft of heinous acts. The Government responded to the demands to act by lining up the Security Laws (Amendment) Bill 2014 ${ }^{42}$ that can be said to have constituted what would have been arguably the biggest rollback on civil rights in the country since the Moi years. ${ }^{43}$ It put in jeopardy, variously, ${ }^{44}$ the right to freedom of expression and the right to freedom of the media, ${ }^{45}$ the right to privacy, ${ }^{46}$ the rights of an arrested person, ${ }^{47}$ and the right to fair trial, ${ }^{48}$ the entitlement to citizenship and registration of persons, ${ }^{49}$ the right to freedom of movement ${ }^{50}$ and the rights of refugees. ${ }^{51}$ After a brawl, ${ }^{52}$ the Bill was passed and soon after assented by the President. ${ }^{53}$ It is the courts that intervened to preserve the rights that were under

42 Now the Security Laws (Amendment) Act 2014. See the original Bill, as was, here: http://www. knchr.org/Portals/0/Bills/THE\%20SECURITY\%20LAWS\%20AMENDMENT\%20BILL\%20 2014.pdf on 15 May 2015.

43 The term 'the Moi years' is parlance in Kenya, used in reference to the years in Kenya in which Daniel Arap Moi was President, between 1978 and 2002. See Mutua M, 'Justice Under Siege - The Rule of Law and Judicial Subservience in Kenya’ 23 Human Rights Quarterly, 1(2001), 96 - 118.

44 In question was the Constitutionality of the Sections 4, 5, 6, 12, 15, 16, 19, 20, 21, 25, 26, 29, 34, $48,56,58,64,69,85$ and 86 of the Act and the corresponding provisions in various Acts that they amended/ introduced into the law.

45 Guaranteed under Article 33 and Article 34 of the Constitution of Kenya (2010).

46 Guaranteed under Article 31 of the Constitution of Kenya (2010).

47 Guaranteed under Article 49 of the Constitution of Kenya (2010).

48 Guaranteed under Article 50 of the Constitution of Kenya (2010).

49 Guaranteed under Article 12 of the Constitution of Kenya (2010).

50 Guaranteed under Article 39 of the Constitution of Kenya (2010).

51 Under Articles 2(5) and 2(6) of theConstitution of Kenya (2010), International Agreements and Conventions ratified by the nation also become law and should be respected by the state.

52 The conduct of the Kenyan National Assembly that day can only be described as appalling. Tensions were high from the onset. The opposition, under no illusions that they had been outnumbered and would easily be defeated in an open vote, decided to shout down any debate in the House with revolutionary song. Unable to move forward, the session was adjourned to resume in the afternoon and when afternoon came, the ruling coalition arrived back clearly prepared for the race to the bottom. Scenes such as water being splashed on the presiding Speaker, a Member of Parliament having his trousers torn and another Member of Parliament having his finger bitten off became prime time news conversation. More on this session of the National Assembly can be read here: http://www. theguardian.com/world/2014/dec/18/fights-kenya-parliament-anti-terrorism-laws on 11 May 2015 and watched here: http://www.youtube.com/watch?v=Zw49umKgfNU on 11 May 2015.

53 See more here: http://www.businessdailyafrica.com/President-signs-new-security-laws//539546/2562660/-/4llxsp/-/index.html on 15 May 2015 for President Kenyatta's assent. It is the author's opinion that this was an attempt by government to use its power to make laws to get quick results in the war against terrorism. This is rule by law. It can be distinguished from rule of law, according to political science professor Shuguang Li: "The difference is that, under the rule of law, the law is preeminent and can serve as a check against the abuse of power. Under rule by law, the law 
threat. It declared some provisions of the Act a nullity while upholding the more reasonable ones. ${ }^{54}$ This is the general tangent of the temptation of power. Under pressure to stem the attacks, the state becomes impatient and decides that it will do what it believes it takes, legal or not, to put an end to the attacks. Indeed, it is a signature of the Government's determination that even before the Court, the team that represented the State was a high profile one, with the Director of Public Prosecutions appearing as an interested party, but leaving few if any qualms as to his stand on the Act. ${ }^{55}$ On this occasion, the Court dutifully intervened to prevent the rupture of the membrane of law. ${ }^{56}$

The membrane of law almost burst once more, this time in a way that would have been very damaging to the rule of law in Kenya, after the attack on the Garissa University College. In the now-customary ${ }^{57}$ address to the nation after the attack, the President, ignoring a Court order in place, ${ }^{58}$ directed that the ten thousand recruits whose enrolment the Court had cancelled due to allegations

is a mere tool for a government that suppresses in a legalistic fashion." See Tamanaha B, On the Rule of Law, Cambridge University Press, 2004, 3.

54 See the Consolidated Petition No.630 of 2014 \& Petition No.12 of 2015;

Between the Coalition for Reform and Democracy (CORD) (the $1^{\text {st }}$ Petitioner), the Kenya National Commission of Human Rights (2 ${ }^{\text {nd }}$ Petitioner), Samuel Njuguna Ng'ang'a (3rd Petitioner) and the Republic of Kenya (1 ${ }^{\text {st }}$ Respondent), the Attorney General (2nd Respondent) [2014] eKLR. See the judgement here: http://www. shitemi.com/wp-content/uploads/2015/02/Security-Laws-Judgement.pdf on 11 May 2015.

55 This particular occurrence was interesting because the Director of Public Prosecutions has rarely appeared in court since taking office. This author can only recall three such events, one of which is this particular case. The other two are when fresh charges were opened on seven Anglo-Leasing corruption scandal suspects, and when Members of Parliament from Narok region were charged with incitement at the Milimani Law Courts in Nairobi. See more at: http://www.youtube.com/ watch?v=topL1u8oXKw on 11 May 2015. This might show the seriousness with which the government took the issue. The DPP appeared as an interested person and argued for the Court to uphold the Act in its entirety.

56 It is the author's note that the decision by the Court on this occasion ranked high up there with some of the most progressive in the world today, for instance a watershed ruling given on 16th December 2004 in the United Kingdom where the House of Lords, in an 8 to 1 majority, overturned a prior decision of the Appeals Court and held that the preventive detention provisions of a 2001 Act were in breach of the European Convention on Human Rights: A and others $v$ The Secretary of State of the Home Department [2004] UKHL 56. In essence the House of Lords held that there was no state of public emergency that threatened the life of the nation enough to justify such a decision. Rather, Lord Hoffman in a memorable and scathing passage of his opinion, said: 'The real threat to the life of the nation, in the sense of a people living in accordance with its traditional laws and political values, comes not from terrorism but from laws such as these.'

57 See Bennett T, Critical Trajectories: Culture, Society, Intellectuals, 141-163.

58 The order given by High Court Judge Justice Isaac Lenaola quashed the Police Recruitment exercise that took place in 36 recruitment centres around the country on 14 July 2014, and ordered that fresh recruitment take place. See: Independent Policing Oversight Authority \& another v Attorney General \& 660 others [2014] eKLR. 
of corruption be enrolled. ${ }^{59}$ The President went on to say that he would take 'personal responsibility' for the order. The blowback, and this the rule of law will be thankful for, was instant. ${ }^{60}$ After a few days, within which one could not miss some of the apologia that was used to defend the President's directive, ${ }^{61}$ the President folded and rescinded his order. In doing so, he spared the country a very public trial of strength between the Presidency and the Judiciary ${ }^{62}$ that would have set back the rule of law. Perhaps President Kenyatta was having his 'President Jackson moment ${ }^{63}$ or perhaps he wanted to make it clear that Government was getting serious with the war against terror; shorn of the advantage of reading his own reasons on record, one can only leave that task to speculation. What is clear, however, is that once more, the attack had created pressures that were being feltthus the temptation of power- the attempt to issue an unconstitutional order.

59 See the in full the President's address to the nation that contained these directions here: http:/ /www. khcwindhoek.com/?p=884 on 11 May 2015.

60 The Commission on the Implementation of the Constitution accused the President of violating the Constitution, see: http://allafrica.com/stories/201504090038.html on 11 ${ }^{\text {th }}$ May 2015 while the Independent Policing Oversight Authority (IPOA) declared that it would go to Court to challenge the President's directive, see: http:// county-411.com/ipoa-to-challenge-president-uhuru-kenyattasdirective-on-police-recruits-in-court/ on 11 May 2015.

61 In this regard, two men come to mind. The first is the Attorney General, who clearly had some difficulty rationalising the order, preferring to instead discuss 'a round table discussion' that he was assembling with the IPOA and other security agencies, see: http://www.businessdailyafrica.com/ Muigai-seeks-out-of-court-deal-on-police-recruits-saga/-/539546/2679774/-/n0bfstz/-/index. html on 11 May 2015. The second is Elgeyo-Marakwet, Senator Kipchumba Murkomen, who is arguably one of the finest legal minds in the country, holding two Masters of Law degree (LLM) from the American University (Washington College of Law) in the United States and University of Pretoria, South Africa — and has lectured the Catholic University of Eastern Africa, the University of Nairobi, and Moi University, Eldoret. Invited to contribute to a Monday prime time news discussion on Citizen TV about the President's decision, the Senator explained how 'the nation is in a state of war' and that this excused the President's action. Reminded by his fellow panellist that there is an elaborate procedure in Article 58 of the Constitution of Kenya (2010) to be followed if the President wanted to declare a state of war or emergency, he could only continue to offer that 'the judiciary is the one that is failing Kenyans.'

62 The Judiciary responded with a statement of its own, issued by Director of Public Affairs and Communications, Naim Bilal who, citing Article 162 of the Constitution of Kenya (2010), said that the state's appeal against the quashing of the initial recruitment exercise had been fast-tracked and added that due process must be allowed to take its natural course. In his own words, "It is important that the judges be allowed to make the determination on the matters before them as guaranteed by Article 162 of the Constitution of Kenya (2010) without appearing to exert undue pressure on them. The judges will reach a determination based on the facts and the law, " he said. See more at: http://www.capitalfm. co.ke/news/2015/04/let-judges-do-their-jobs-judiciary-tells-uhuru/ on 12 May 2015.

63 The author uses this allusion to refer to the popular quotation that is believed to be apocryphal, where President Andrew Jackson reportedly responded to the United States Supreme Court decision in Worcester v. Georgia 31 U.S. (6 Pet.) 515 (1832), which he disagreed with, by saying: "John Marshall has made his decision; now let him enforce it!" John Marshall was the then-American Chief Justice and sat in the bench that made the decision. 
In that scenario, the membrane of law had again been stretched very publicly, but restored in time to prevent its breaking. Here one must linger, for a public, declared, unconstitutional action by the state is far more damaging than one that is done covertly. It has been said by some that the rule of law is itself a myth, and whilst that may be arguable ${ }^{64}$ what is inarguable is that the rule of law, myth or not, needs to be sustained and for arbitrariness by those in power to be discouraged in a society. And the way that the rule of law is weaved into society is through making it a custom, a culture.$^{65}$ American Supreme Court judge Justice Stephen Breyer has also said as much. ${ }^{66}$ Thus when the President himself announces that he is prepared to break the law and 'take personal responsibility' over the matter, then the message sent to the nation is that this country is one of men and not of laws. ${ }^{67}$

Finally, and because it is unusual ${ }^{68}$ yet deserves special mention, let us con-

${ }^{64}$ See Hasnas J, The Myth of the Rule of Law' 199 Wisconsin Law Review (1995), wholly relevant. See also Bingham T, The Rule of Law, Penguin Publishers, February 2011 re-print, wholly relevant.

65 This author remembers the question of how the rule of law is inculcated into a society being responded to by a panel of guest speakers at the International Conference on Transformative Constitutions that took place at the British Institute of Eastern Africa and the Sarova Panafric Hotel in Nairobi between June $9^{\text {th }}$ and $11^{\text {th }} 2014$. Among the guests who responded were Professor Kenneth Roach, Professor \& Prichard Wilson Chair in law and public policy at the University Of Toronto Faculty Of Law, and Justice Kemal S. Bokhary who is a Judge on the Hong Kong Court of Final Appeal. Both men responded most succinctly, making it clear that there was 'no magic or formula to it', and that only when there is a culture and custom of following the law will the rule of law flourish in a country.

${ }_{66}$ See Breyer S, Making Democracy Work, A Judge's View, Vintage Publishers, September 2011, 63.

${ }_{67}$ As opposed to the original quote that "the government, country or state is one of laws and not of men" attributed to Aristotle and AV Dicey. In his memorable oath of office after taking charge as President following President Richard Nixon’s resignation, American President Gerald Ford also said "Our Constitution works; our great Republic is a government of laws and not of men. Here the people rule." See more at: http://www.history.com/topics/us-presidents/gerald-r-ford/videos/ inaugural-address-gerold-ford on 12 May 2015.

68 It is unusual because it is not clear that the pressures that the author comes up with in the paper, that is public mood spurred on by the media, are what led to it. While it is true that there were always pressures that led to the action, it may be that these pressures were different from the ones that this paper attempts to compile as leading to the temptation of power and it will be fortuitous to attempt to understand this pressures, not least because of the lack of transparency of this operation. It is, however, speculated in a report by Crisis Group, The Kenyan Military Intervention in Somalia Crisis Group Africa Report No184, 15 February 2012 (page 3, footnote 27 of the Report) that "the political leadership did not go to this war after months of planning, analysis, budget allocation.... it went to this war purely to soothe the Western tourist circuit and gain political mileage and also probably to distract Kenyans' attention from the fight over next year's general elections date, " Crisis Group email correspondence, former Kenya army officer, November 2011. See here the report link: www.crisisgroup.org/ /media/Files/africa/horn-of-africa/kenya/184 - The Kenyan Military Intervention in Somalia on 8 December 2015.

See the report here: http://www.crisisgroup.org/ /media/Files/africa/horn-of-africa/ 
sider 'Operation Linda Nchi', the military operation that sent over three thousand Kenyan soldiers into Southern Somalia to 'pursue Al Shabaab and other armed terrorist elements, that had sought to destabilise our country, our economy and the region. ${ }^{69}$ It is critical to note that this paper is not going into the question of whether this operation was and remains right or wrong, or whether it is this operation that has led to the rampant attacks $;^{70}$ for that would mean an entirely new paper, or perhaps an excursus, in itself, and because besides a book published one year ago, ${ }^{71}$ official information on the operation is difficult to come by. ${ }^{72}$ What this paper is going to show is how the decision to go into the war was made.

That the nation knew little of the operation until two days after the intervention $^{73}$ says much about the transparency that Government allowed. Yet

kenya/184\%20\%20The \%20Kenyan\%20Military\%20Intervention\%20in\%20Somalia.pdfon 15 May 2015.

69 These reasons are taken directly from then-President Mwai Kibaki's speech to the gathering at the London Conference on Somalia on $23^{\text {rd }}$ February 2012 at Lancaster House, London, Para. 5. Read the whole speech here: http://www.kenyaembassyaddis.org/wp-content/uploads/speeches/ presidential/LONDON_CONFERENCE_ON_SOMALIA_23RD_FEBRUARY_2012.pdf on 15 May 2015.

70 It cannot, however, be lost on any keen observer that between 2002 and 2011 it is not easy to find any recorded terrorist attack by the Al Shabaab in the country. According to Kenya's Anti-Terrorism Police Unit, the country has suffered 133 terror-related attacks - one every eight days - since the offensive began. It is difficult to see this as a coincidence that was bound to happen. Even more interestingly, Robert Pape, a University of Chicago political science professor and former Air Force lecturer, recently presented findings to the US Congress that argue that the majority of terrorism attacks around the world since 1980 have had a common cause: military occupation. Pape and his team of researchers draw on data produced by a six-year study of terrorist attacks around the world that was partially funded by the Defence Department's Defence Threat Reduction Agency. They compiled the terrorism statistics in a publicly available database comprising some 10,000 records on some 2, 200 terrorist attacks, dating back to the first suicide terrorism attack of modern times - the 1983 truck bombing of the U.S. Marine barracks in Beirut, Lebanon, which killed 241 U.S. Marines.

71 See the book, Migue T, Operation Linda Ncbi: Kenya's Military Experience in Somalia, Kenya Literature Bureau and Worldreader, 14 October 2015. Although seen as a significant improvement in transparency and openness in state affairs, the book has also been criticised by book reviewer John Ngirachu as being 'under the eye of the military authors'; of overkill in being preoccupied with describing the necessity and accomplishment that taking Kismayu was; and of giving little information about what exactly the military is doing in Somalia and how the Al-Shabaab can still have the capacity to strike in our country.

72 There is no official government report online and what one is left to examine is the correspondence on the Social Media site Twitter and news reports. These news reports are in themselves questionable, for most of them apply a phenomenon called 'war reporting' rather than 'peace reporting.' 'War reporting' is a way in which the press reports a conflict to feed society's needs, in this case by showing Kenyan soldiers winning the war on terror. It is a market-driven approach to news that conceptualizes as a market. See Ogenga F, 'Is Peace Journalism Possible in the War against Terror in Somalia' 11 Conflict and Communication Online, 2 (2012), 3.

73 Read The Kenyan Military Intervention in Somalia Crisis Group Africa Report N¹84, 15 February 2012, 3. Find it here:www.crisisgroup.org/ /media/Files/africa/horn-of-africa/kenya/184 - The 
perhaps that opacity was required so as not to give the enemy information to threaten the security of our troops. What is outstanding is that the decision to send these troops to Somalia was never presented ${ }^{74}$ to Parliament, yet Article 132 (4) (e) of the Constitution of Kenya (2010) requires that Parliament approve any war effort. ${ }^{75}$ Neither the people nor the representatives of the people gave their imprimatur for this intervention to take place. It may be argued that this is not 'a war' in the literal sense of the word, but even this would be reading the Constitution of Kenya pedantically and contrary to Article 259, which states that the Constitution is a living document that must be interpreted widely. ${ }^{76}$ Without examining the merits of this decision, this paper puts forward that it has set a bad precedence for the rule of law in Kenya, keeping in mind that many times before and after this, the military has been deployed within the country, ${ }^{77}$ again without approval from Parliament, and is documented to have committed many human rights abuses against civilians. ${ }^{78}$

\section{ii. The rupturing of the membrane of law and the damage done to hu- man rights and society}

Sometimes the membrane of law ruptures. While this rupture is hard to see for one who is not directly affected, it is eventually inescapable, partly thanks to the media.

To accurately show how temptation of power leads to the rupturing of the membrane of law and the results that follow, one has to go to only one

Kenyan Military Intervention in Somalia.pdf on 15 May 2015.

74 Read The Kenyan Military Intervention in Somalia Crisis Group Africa Report No184, 15 February 2012, 3. The intervention was discussed and approved by the cabinet on 18 October. See Leftie P, 'Kenya, Somalia seal pact to hit Shabaab', Daily Nation, 19 October 2011.

75 Article 132 (4) (e) of the Constitution of Kenya (2010), reads that 'The President may, with the approval of Parliament, declare war.'

76 Article 259 (1) reads that 'this Constitution shall be interpreted in a manner that - (a) promotes its purposes, values and principles; (b) advances the rule of law, and the human rights and fundamental freedoms in the Bill of Rights; (c) permits the development of the law; and (d) contributes to good governance.'

77 Consider that the Kenya Defence Forces were deployed in Lamu after the Mpeketoni attacks and in Kapedo to quell cattle rustling, see : 'West Pokot leaders demand withdrawal of KDF from Kapedo, threaten to sue at ICC' here: http://www.standardmedia.co.ke/thecounties/Article/2000140878/ west-pokot-leaders-demand-withdrawal-of-kdf-from-kapedo-threaten-to-sue-at-icc on 16 May 2015.

78 A Kenyan army operation against the Sabaot Land Defence Force is, for instance, said to have left over 600 people dead and terrorised thousands more in the Mount Elgon area close to the Ugandan border. This is typical of KDF operations. Read The Mountain of Terror, A Report on the Investigations of Torture by the Military at Mt. Elgon, May 2008 by the Kenya National Commission on Human Rights. 
place in Kenya: the Coast region. For, in the last few years, the Coast has been a cauldron. ${ }^{79}$ Long before it simmered, the first strands of terrorism were seen at the Coast on November $28^{\text {th }} 2002$ when the Israeli-owned 'Paradise Hotel' in Kikambala, fifteen miles north of Mombasa, was attacked by three suicide bombers who drove an explosive-packed car into the gates, killing nine Kenyans and three Israeli tourists. ${ }^{80}$ If these were the proverbial warning shots being fired, there was a huge lull ${ }^{81}$ before those who were giving the warning scaled up their efforts. Eventually, however, they $\operatorname{did} .{ }^{82}$ And the reaction by Government was overwhelming.

If there were any post for key antagonist in the war against terror at the Coast in Kenya, then this post has been fully claimed by the Anti-Terrorism Police $\mathrm{Unit}^{83}$ (hereinafter referred to as the ATPU) which seems to have a recordbreaking catalogue of actions rupturing the membrane of law.

The group Human Rights Watch ${ }^{84}$ found evidence of at least ten cases of extra-judicial killings of terrorism suspects, ${ }^{85}$ some of whom were last seen in ATPU custody or had been threatened by the unit's officers after courts had released them. Several suspects were facing terrorism-related charges, were required to report to the unit either weekly or monthly and had told family and friends they had received death threats from ATPU officers they recognized. In other cases, the threats were issued in the presence of associates that Human Rights Watch says it interviewed. In at least three of the killings, the unit claimed

79 While it is true that the 'major' terrorist attacks have happened outside this County, there have been numerous 'minor' attacks of this sort here. In addition, this County seems to be one of the centres of the so-called 'radicalisation' of the youth who eventually join terrorist groups, see Botha A, Institute for Security Studies, Radicalisation in Kenya: Recruitment to Al Shabaab and the Mombasa Republican Council, September 2014.

80 See more here: http://www.theguardian.com/world/2002/nov/28/israel.kenya on 12 May 2015.

81 From this attack in 2002 , the tension at the Coast and attacks that related to terrorism seemed to resume only since 2011 .

82 The numerous attacks that this author relies on to make the assertion that 'they did' are detailed on pages 1, 2 and 3 of this paper. There were at least 70 grenade and gun attacks in Nairobi, Mombasa, and Garissa between 2011 and 2014, with at least 30 attacks in 2012 alone.

83 The ATPU was created within the Criminal Investigations Department (CID) in 2003 in response to the attacks on the US Embassy in Nairobi in 1998 and on Paradise Hotel in Kikambala, Mombasa, in 2002 .

84 Human Rights Watch is a group that defends the human rights of people worldwide. Find out more about it here: http://www.hrw.org/about on 12 May 2015.

85 Some include Shabaan Namusenda Makotse in April 2013, Sheikh Hassan Suleiman Mwayuyu in December 2013, Hassan Omondi Owiti and Shekha Wanjiru, in May 2013, Khalif Mwangi in May 2013 and Ibrahim Ramadhan Mwasi in June 2013 ; See more here: http://www.hrw.org/ news/2014/08/18/kenya-killings-disappearances-anti-terror-police on 12 May 2015. 
that the suspects were killed in a fire fight. Human Rights Watch said that it did not find evidence of a shootout, as witness descriptions pointed to a short-lived, targeted killing by security officers, and the scene suggested the shooting was unidirectional without any damage to the surrounding buildings as ATPU had suggested. In other cases, the ATPU did not accept responsibility for the killings, but its officers were either seen with the suspects before they were killed or took the bodies to the mortuary without notifying the families.

Under Kenyan and International Law, police may use lethal force only when necessary for self-defence or to save a life. The National Police Service Act of $2011^{86}$ also requires police officers who use lethal fire to report to their immediate superior explaining the circumstances that necessitated the use of force. Similarly, the Act requires officials to report any use of force that leads to death or serious injury ${ }^{87}$ to the Independent Police Oversight Authority ${ }^{88}$ for investigation. Human Rights Watch reported that Police authorities have not complied with these requirements in these cases of extrajudicial killings.

Further, the United Nations Basic Principles on the Use of Force and Firearms by Law Enforcement Officials ${ }^{89}$ requires that law enforcement officials use nonviolent means whenever possible and use lethal force only when it is strictly unavoidable to protect life.

The principles also require governments to ensure that arbitrary or abusive use of force and firearms by law-enforcement officials is punished as a criminal offense under their law. It is almost as if human rights are an unknown quantity when it comes to several actions of the ATPU. A further probe by Human Rights Watch has documented the enforced disappearances of at least ten young men by ATPU officers from Nairobi between 2011 and 2013..$^{90}$ The men faced terrorism-related charges in various Kenyan courts, were under investigation by

86 Section 4, National Police Service Act (Act 11 of 2011).

87 Section 5, National Police Service Act (Act 11 of 2011).

88 The IPOA is an independent authority established under the Independent Policing Oversight Authority Act (No. 35 of 2011) to provide for civilian oversight over the work of the police in Kenya.

89 Find the Basic Principles on the Use of Force and Firearms by Law Enforcement Officials that was adopted by the Eighth United Nations Congress on the Prevention of Crime and the Treatment of Offenders, Havana, Cuba between 27th August and $7^{\text {th }}$ September 1990 here: http://www.ohchr. org/EN/ProfessionalInterest/Pages/UseOfForceAndFirearms.aspx on 12 May 2015.

90 Some of the victims according to the Report by Human Rights Watch included Sylvester (Musa) Opiyo Osodo and Jacob (Yaqub) Musyoka in May 2012, Abdulaziz Muchiri and Ali Kipkoech Musa in May 2013, and Yassin Olunga and Ali Musadiki, last seen in Nairobi in April 2013; See more on this here: http://www.hrw.org/news/2014/08/18/kenya-killings-disappearances-anti-terror-police on 15 May 2015. 
the ATPU, or had been acquitted. All of them had told family members, friends, and associates whom Human Rights Watch interviewed that they received direct death threats from ATPU officers. ${ }^{91}$ On December $8^{\text {th }} 2014$, Aljazeera and JSC (Jazeera Satellite Channel) also aired a documentary titled Inside Kenya's Death Squads' that reported, after investigation and interviews, about a Kenyan government assassination programme targeting suspected Muslim radicals. ${ }^{92}$ The Government denied all allegations and moved to take legal action against the makers of the documentary. ${ }^{93}$

As if giving the orders and having them carried out covertly is not enough, Mombasa County Commissioner, Nelson Marwa, is on record declaring a shootto-kill order on all terrorism suspects. Marwa claimed that it is counter-productive to take terror suspects to court because it is very difficult to prosecute them or find witnesses in their prosecution. ${ }^{94}$

All these actions are orchestrated despite the Constitution being clear that 'The National Police Service shall comply with constitutional standards of human rights and fundamental freedoms. ${ }^{95}$

Thus the other key effect of this succumbing to the temptation of power and the consequent bursting of the membrane of law becomes clear: the disregard for human rights. And here one must dwell. For if there is any situation that should prick the conscience more than any other, it should be the violation of human rights by the very state that is supposed to protect them. Yet what pricks the conscience even more in this nation must be the collective sigh that one could sense has been the national mood when charges of violation of human rights in the war against terror were brought against the Government on several occa-

91 The International Convention for the Protection of All Persons from Enforced Disappearance, which Kenya has not signed, defines an enforced disappearance as "the arrest, detention, abduction or any other form of deprivation of liberty by agents of the state or by persons or groups of persons acting with the authorization, support or acquiescence of the state, followed by a refusal to acknowledge the deprivation of the liberty or by concealment of the fate or whereabouts of the disappeared person, which place such a person outside the protection of the law."

92 Watch the full film here: http://interactive.aljazeera.com/aje/KenyaDeathSquads/ on 14 May 2015.

93 See documents filed in Court here: http://big.assets.huffingtonpost.com/KenyaAlJazeeraDec2014. pdf on 13 May 2015. The suit does not seem to have moved forward since then.

94 Speaking directly to then-Mombasa County Police Commander Robert Kitur, Marwa said the shootto-kill order had been prompted by the fact that criminals gangs had infiltrated the county and it was fair to kill the criminals as it would bring them to the justice they deserve on behalf of the victims. See more here: http://www.standardmedia.co.ke/thecounties/Article/2000107870/police-issueshoot-to-kill-order-on-terrorism-suspects on 12 May 2015.

95 Article 244 (c) Constitution of Kenya (2010). 
sions, and in particular during 'Operation Usalama Watch. ${ }^{96}$ This national mood, as always, was on display by the press. The human rights violations were treated indifferently, almost with a blasé response. Only those directly affected were left to plead and protest. The few who did so and yet had not been directly affected were looked at as the usual maudlin humanitarians who did not need the 'straight' world and whose pleasure it was to cause trouble; to be against. Be patriotic and get behind government in the war against terror, they were told. ${ }^{97}$

And what do these human rights violations do to society?

It was American politician, Barry Goldwater, who was first recorded as saying that 'extremism in the defence of liberty is no vice while moderation in the pursuit of justice is no virtue. ${ }^{98}$ On August $28^{\text {th }} 2012$, a large group of youth in Mombasa seemingly agreed with the cri de coeur and riots gripped Mombasa after Aboud Rogo Mohammed, a controversial Muslim cleric who was suspected of being a key recruiter for Kenyan Muslims fighting in Somalia, was shot dead; ${ }^{99}$ on October $4^{\text {th }} 2013$, a similar situation took place after unidentified gunmen, believed to be the ATPU, shot cleric Ibrahim 'Rogo' Omar and three other people dead in Mombasa as they drove home; $;^{100}$ and on Saturday November $8^{\text {th }} 2014$, it again occurred after unidentified gunmen (police denied involvement but sources within the force said that officers of the ATPU were involved) shot and killed Hassan Guti as he was driving in the city with his wife and niece. ${ }^{101}$

96 This operation, sensationally christened 'Kasarani Concentration Camps' by the Muslim Human Rights Organization (MUHURI) was another government attempt to rein in on the rampant attacks. It took place in July 2014 and saw the roundup of hundreds of people of the Somali Community at the Kasarani Stadium. See more here: http://allafrica.com/stories/201407031424.html on 12 May 2015.

97 These words came from a wide-ranging interview that the author had with one of the Directors of MUHURI (notes with the author). The same theme was being driven by the politicians who appeared on prime time news to discuss the matter. Politicians from the opposition coalition who raised the matter of human rights violations seemed to be raising it merely to show what they considered the inept nature of government.

98 See the text of Barry Goldwater's 1964 speech at the 28th Republican National Convention, accepting the nomination for president here: http://www.washingtonpost.com/wpsrv/politics/ daily/may98/goldwaterspeech.htm on 7 December 2015. This theme was first advanced by Mr. Goldwater at the Republican Convention of 1964 and adopted as their own, and at the Democratic Convention of 1968, by the rioters and the police who responded to them.

99 See more here: http://www.bbc.com/news/world-africa-19394364 on 12 May 2015.The state should, nevertheless, receive praise for constituting an inquest into this killing, see more here: http://www.standardmedia.co.ke/thecounties/Article/2000110518/sheikh-aboud-rogo-killerswere-arabs-inquest-hears on 13 May 2015.

100 See more here: http://www.bbc.com/news/world-africa-24398548 on 12 May 2015.

101 See more here: www.nation.co.ke/counties/mombasa/Hassan-Guti-alias-Nasralla-shotdead/-/1954178/2515998/-/mb670xz/-/index.html on 7 December 2015. 
These were no run-of-the-mill riots as the rioters engaged police in running battles and the city was shut down for days. And as the men who reported the revolution in China years ago found out, by the time the guerrilla forces surfaced in any province, political infection had metastasized there too deeply to be stopped. The situation at the Coast was almost similar, and many times since then, and particularly after Friday prayers, police have been forced to deploy heavily to deter rioting. Mombasa remains restless. This is what a society in breakdown experiences. This is what happens when the human rights of a group of people, no matter how minor, are ignored. These people react ${ }^{102}$ and it is even more instructive that a poll released by South Africa's Institute of Security Studies (ISS) suggests that Kenya's response to terrorism may have aggravated the crisis and that many Muslim youths have joined extremist groups in reaction to the Government's collective punishment of Muslims and assassination of religious leaders. ${ }^{103}$

So what does this paper recommend that the state does?

\section{By Way of conclusion}

It is not lost on this author that one may make accusations, plausible or not, that this paper is living in a world of its own; that these are the usual ideas from an academic who is sipping café lattes under palm trees thinking up new ideas; ${ }^{104}$ that this paper is but part of those that write and betray the derivative intellectual scorn that exists in men who profess a higher morality rather than, and for, those who must compromise with reality or settle for less than perfect in order to make things work now.

102 It is interesting to note that the situation in the Coast and in particular in Mombasa, is far from calm. The closure of the mosques that followed in another swoop only heightened matters. See more here: http://www.coastweek.com/3747-Tension-high-in-Mombasa-as-police-intensify-mosque-raids.htm on 12 May 2015.

103 See Institute for Security Studies Africa, 'Is Kenya's response to terrorism making it worse?'15 October 2014. See it here: http://www.issafrica.org/about-us/press-releases/is-kenyas-response-toterrorism-making-it-worse on 16 May 2015.

104 The quote is taken from a Stanford Law Review panel discussion titled 'Do inmates run the asylum?', para. 19 in which James Brosnahan, then a partner in Morrison \& Foerster and a practicing trial lawyer, agreed that law reviews have become more theoretical, but he urged the editors not to listen to those who say theory is not interesting to lawyers and judges in the field. In his own words, "The concept that over in academia, and sipping café lattes, is a world of thought, and out beyond are grinding practitioners with old briefcases who care nothing for ideas - that's a destructive idea. It's doing enormous damage to the practice of law and the way the public views lawyers in the United States." 
The truth is that this author appreciates the existential threat that these terrorist attacks have come to pose to our nation. What is unacceptable is the charge that we must now be willing to sacrifice the rule of law and individual rights, for human rights are by nature supposed to be person by person ${ }^{105}$ and indeed, that this can be done without due process. It is the re-enactment of the American Government's conduct in Korematsu. ${ }^{106}$ And what leads to the state taking such an approach are the pressures that come with each attack, and that lead to the temptation of power.

This paper proposes first, that we address these pressures that lead to the temptation of power and then to the stretching or breaking of the membrane of law. To address these pressures is to address the issue of public mood and the press. And to address the issue of the press is to address public mood. Yet on the issue of the press, the best one can do is to urge and hope ${ }^{107}$ that even with a profit motivation, it can understand its place in conditioning public mood and use its power responsibly. This paper proposes that one way through which the press can de-escalate this is by focusing its reporting on highlighting institutional gaps and failures (and pressuring for action on these) as much as it does placing the blame on individuals, and too widely at that. ${ }^{108}$ In this way one of the key pressures that lead to the temptation of power will be eased, and the pressure on those in power will be to act to fix the institutions, not to earn credit and preserve themselves through unconstitutional actions.

This paper posits that the press should also use its power to back human rights and the rule of law more robustly. It must speak out when these are violat-

105 See the opening of the Universal Declaration of Human Rights here: http://www.un.org/ Overview/rights.html on 12 May 2015.

106 Korematsu v. United States, 323 U.S. 214 [1944] was a landmark United States Supreme Court case concerning the Constitutionality of Executive Order 9066, which ordered Japanese Americans into internment camps during World War II regardless of citizenship. The court then went on to uphold the order but is today widely repudiated, with the United States Justice Department even urging, and the Courts following, its termination as precedence.

107 Because creating Legislation on such an issue will curtail the Freedom of the Media, guaranteed under Article 34 of the Constitution of Kenya (2010).

108 After each terrorist attack, there was a narrative, driven in no small part by the press, that those who were in charge of the security of this nation had no idea what they were doing. Then-Cabinet Secretary Joseph Ole Lenku and Inspector General of Police David Kimaiyo were especially victims. The press, sadly for this author, did not charge with specifics; nor did they take as much time to highlight the gaps in these institutions that deal with security. What the author hopes is that the Press can see and highlight, with equal gusto, that the attacks are not just the story of the Inspector General of Police or the Cabinet Secretary being incompetent as many would claim, but part of a nationwide phenomenon, a disease of the system itself. 
ed as loudly as it does when the state trains its sights on curtailing media rights. ${ }^{109}$ It is this author's hope that journalists in Kenya can take a cue from one Edward R. Murrow in this regard. In a career spanning twenty-five years at the Columbia Broadcasting System, he bequeathed to those who worked for and with him something more important than opportunity and fame: he bequeathed a sense of conscience and importance with which neither management nor government could interfere. His concept of public advocacy emboldened him to speak for the African-Americans against government, for the poor against landlords and for the hungry against the establishment. ${ }^{110}$

The presence of the pressures are, nonetheless, not an excuse for taking unconstitutional actions and this paper then proposes that the government insists on all its officials preserving the membrane of law in all their actions and makes sure that those who take actions that contradict this insistence face consequences and it is this author's opinion that the consequences for officials who take unconstitutional and/ or extra-constitutional actions should range from a severe reprimand (if the membrane of law is only strained) to being charged in Court (should the membrane of law be ruptured by an action). Government should,

109 During the debate that ensued about the Security Laws Amendment Act (Act No 19 of 2014), the Media was at pains to highlight and continuously debate the clauses that affected them. The Penal Code had been amended to include Section 66 which provided that any person who publishes gory or offensive material likely to disturb public peace or order will be guilty of a felony and may be fined up to 1 million shillings or be imprisoned for 3 years while a media enterprise guilty of the same action would be liable to a fine of up to 5 million shillings.

The Prevention of Terrorism Act was also amended to include Section 30A in relation to publication of offending materials. It stated that "A person who publishes or utters a statement that is likely to be understood as directly or indirectly encouraging or inducing another person to commit or prepare to commit an act of terrorism commits an offence and is liable on conviction to imprisonment for a term not exceeding 14 years." The Section also established a threshold under which such incitement can be inferred; either when the circumstances and manner of the publications are such that it can reasonably be inferred that it was so intended or the intention is apparent from the contents of the statement.

Another significant Amendment under the Prevention of Terrorism Act was Section 30F which stipulated that any person who publishes or broadcasts any information that would be seen to undermine security operations or investigations related to terrorism without the authorisation of the National Police Service is guilty of a felony and could be jailed for up to 3 years or fined 5 million shillings. Also, a person who publishes photographs of victims of a terrorist attack without the authorisation of the National Police Service would also be liable with similar penalty. Perhaps even more intriguing was the fervour with which the major Media Houses in Kenya fought the Communications Authority of Kenya between January and February 2015 during the Digital Migration crisis when they began their bulletins with 2 to 3 news items every day highlighting what they believed was unfair conduct by the CAK towards them.

110 White T, The Making of the President 1972, 274. See also: http://dca.lib.tufts.edu/features/murrow/ exhibit/ on 15 May 2015. There is also a film on his exploits, particularly his fight with Senator Joe McCarthy by the name 'Good Night and Good Luck.' 
moreover, turn its focus towards restoring the authority of the institutions that have a bearing on the security of Kenyans. In this regard, one might name the National Police Service, ${ }^{111}$ the National Intelligence Service, ${ }^{112}$ the Criminal Investigations Department, ${ }^{113}$ the Office of the Director of Public Prosecutions, ${ }^{114}$ the Department of Interior, ${ }^{115}$ the Ethics and Anti-Corruption Commission ${ }^{116}$ and the Witness Protection Agency ${ }^{117}$ among others. For it is the erosion of the authority of some of these institutions (a mysterious process ${ }^{118}$ of which the most that can be said is that once it starts, it tends not to stop) that has enabled these attacks. This task will no doubt be challenging. It will require that the President leads as Government takes the fight to the 'mobs' that are holding these institutions hostage: for instance the millionaires who benefit from each corrupt deal and those who could care less about merit.

Government should try to follow this blueprint because at the end of the day, terrorism is but a criminal action that is heightened; indeed, a 'normal' criminal wants to merely enrich himself while a terrorist is a criminal who sees himself a revolutionary. Not just a revolutionary, but a revolutionary of the confessional type, who is always the most difficult for the authorities to handle. He

111 Established under Article 245 of the Constitution of Kenya (2010), and Cap 84, the National Police Service Act (Act 11 of 2011).

112 Established under Article 242 of the Constitution of Kenya 2010 and the National Intelligence Service Act (Act No. 28 of 2012).

113 Which is under the National Police Service.

114 Established under Article 157 of the Constitution of Kenya (2010), and The Office of the Director of Public Prosecutions Act (Act No. 2 of 2013).

115 Cabinet docket in Kenya that is in charge of Security. The Department was created under Article 152 of the Constitution of Kenya (2010). It is the opinion of this author that the responsibilities under the docket are overwhelming and, as such, it might be prudent to create a Department to deal exclusively with terrorism issues. This will still leave the total number of dockets below the Constitutional cap of 22 .

116 Rampant corruption has been seen to pose a huge setback in the war against terrorism, especially within the Department of Immigration, and in border control. The Ethics \& Anti-Corruption Commission, established under Article 230 of the Constitution of Kenya (2010), and the Ethics \& AntiCorruption Commission Act (Act No. 2 of 2011) seems constantly embroiled in turf wars and unable to fulfil its mandate beyond mere talk, see more here: http://www.theguardian.com/world/2015/ mar/19/corruption-has-opened-door-to-al-shabaab-in-kenya on 12 May 2015.

117 The Witness Protection Agency of Kenya was set up under the Witness Protection Act 2006 and the Witness Protection (Amendment) Act 2010. Both of these Acts are available on eKLR. It is the opinion of the author that this agency is weak and underfunded by the exchequer, and this hampers it from playing the key role that it can play in helping the state win the war on terror. Those with information on the recruitment and terrorist activities are not assured of safety and have no reason to give this information to the authorities. Its strengthening is crucial and should be prioritised.

118 A process that then-Harvard Professor Daniel Patrick Moynihan valiantly attempted to study in 1969. 
will therefore do whatever it takes, including killing as many people as possible, for the cause. The holes in the whole system that enable criminality are what Government should attempt to plug, because it is these holes that enable normal criminality that also enable the heightened criminality that is terrorism. And most importantly, these holes can be plugged in a legal way; this author proposes, for instance, fighting border-point corruption; ensuring that police officers are well-recruited, well-motivated, well-equipped and posted; and increasing efforts towards counter terrorism - for example, by passing legislation targeting education and jobs in places that are at the heart of the effort to recruit the youth into these terror groups.

Terrorism is indeed a skein of many threads and if one must pull a single root thread from the tangle, it is well to start with positive action geared towards ending the hopelessness and joblessness in these areas. Only through the State vying to win the hearts and minds of the would-be recruits in this way will it be dealing with terrorism in the long term. And winning the hearts and minds is just as important because sometimes, amid all the mire, we forget that terrorism is a human problem. Indeed, as Cassius is recorded to have said to Brutus, 'the fault, dear Brutus, is not in our stars, but in ourselves. ${ }^{119}$

119 Shakespeare, Julius Caesar, Act 1, Scene 2, 6. 